\title{
Current Research: Archaeological Investigations at the Shackleford Creek Site (41SM494), Smith County, Texas
}

Timothy K. Perttula

Heritage Research Center, Stephen F. Austin State University

Bo Nelson

Heritage Research Center, Stephen F. Austin State University

Follow this and additional works at: https://scholarworks.sfasu.edu/ita

Part of the American Material Culture Commons, Archaeological Anthropology Commons, Environmental Studies Commons, Other American Studies Commons, Other Arts and Humanities Commons, Other History of Art, Architecture, and Archaeology Commons, and the United States History Commons

Tell us how this article helped you.

This Article is brought to you for free and open access by the Center for Regional Heritage Research at SFA ScholarWorks. It has been accepted for inclusion in Index of Texas Archaeology: Open Access Gray Literature from the Lone Star State by an authorized editor of SFA ScholarWorks. For more information, please contact cdsscholarworks@sfasu.edu. 
Current Research: Archaeological Investigations at the Shackleford Creek Site (41SM494), Smith County, Texas

\section{Creative Commons License}

\section{(c) (1) (8)}

This work is licensed under a Creative Commons Attribution-NonCommercial 4.0 International License 


\title{
Current Research:
}

\section{Archaeological Investigations at the Shackleford Creek Site (41SM494), Smith County, Texas}

\author{
Timothy K. Perttula ${ }^{1}$ and Bo Nelson ${ }^{2}$ \\ ${ }^{1}$ Archeological \& Environmental Consultants, LLC \\ ${ }^{2}$ Tejas Archaeology
}

An archaeological survey in 2018 of the proposed Shackleford Creek Residential Development, a federally permitted project, in the upper Angelina River basin in East Texas by Tejas Archaeology (Nelson and Perttula 2018) identified the ancestral Caddo Shackleford Creek site (41SM494). Because the site was only investigated with a few shovel tests during the archaeological survey, although sufficient to identify the site extent and general characteristics of deposit depth and artifact content, but appeared to contain intact archaeological deposits of ancestral Caddo age, Nelson and Perttula (2018) recommended that the site warranted further evaluation by a plan of test excavations to determine its research potential and eligibility for inclusion in the National Register of Historic Places (NRHP). Tejas Archaeology completed the test excavations in February 2019 (Perttula et al. 2019).

The test excavations at the site first consisted of 15 shovel tests to better define its intra-site character, especially spatial artifact patterning, followed by the excavation of $101 \times 1 \mathrm{~m}$ units in several areas of the site; flotation samples were taken from columns in several levels in several of the units to recover preserved plant remains and faunal remains in context. This work in total indicated that there are vertically and horizontally discrete archaeological deposits in a loamy sand $\mathrm{A}$ and E-horizon that ranged from $62-97 \mathrm{~cm}$ bs. The Shackleford Creek site covers a ca. 1460 square meters of an upland landform in the upper Angelina River basin in East Texas (Figure 1).

There are two clusters of shovel tests with higher artifact densities identified at the Shackleford Creek site, one in the northern part of the site that is associated with Feature 1, a dark brown and charcoalflecked anthropogenic deposit (Feature 1), and a second cluster about 10-15 m to the south-southwest. These two clusters likely represent areas of more concentrated activity during the ancestral Caddo occupation at the

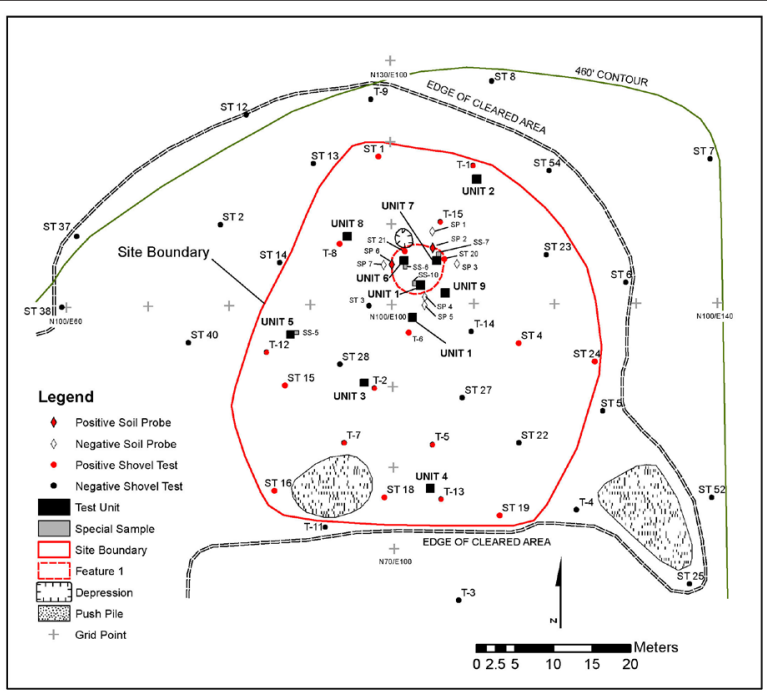

Figure 1. Map of the Shackleford Creek site showing its boundaries, locations of positive and negative shovel tests, shovel probes, $1 \mathrm{x} 1 \mathrm{~m}$ units, and the extent of Feature 1.

site as well as the discard in these places of more broken artifacts and trash.

Feature 1 was originally considered a midden deposit because of its dark coloring or melanization, but due to the relatively low density of charred plant remains and animal bones in this zone, it is now interpreted as an anthropogenic deposit likely associated with the construction and use of an ancestral Caddo house structure that had received or had accumulated a significant organic contribution, likely from habitation debris in and around the house structure. Feature 1 is ca. $6 \mathrm{~m}$ in diameter with deposits that extend from ca. 5-6 $\mathrm{cm}$ bs to $37-44 \mathrm{~cm}$ bs (Zone 2). The feature has organic remains and discarded artifacts, particularly ceramic vessel sherds, as well as many small pieces of burned clay, that became incorporated in the loamy fine sand E-horizon. A second feature was identified in the test excavations at the Shackleford Creek site. This is a post hole (Feature 2) associated with Feature 1, exposed first 
at the base of the Zone 2 deposits, and extending to 102 $\mathrm{cm}$ bs. Ancestral Caddo ceramic sherds and pieces of burned clay were in the feature fill.

The archaeological deposits at the Shackleford Creek site include plain $(n=187)$ and decorated ceramic vessel sherds $(n=305)$, ceramic pipe sherds $(n=4)$, burned clay $(n=230)$, daub $(n=1)$, chipped stone tools $(n=3)$, lithic debris $(n=59)$, and a modified red ochre pebble. The plain to decorated sherd ratio of the assemblage is 0.61 , consistent with both ca. A.D. 1480-1560 and ca. A.D. 1560-1680 Frankston phase components in the region (see Perttula et al. 2019:Table 15), but the overall stylistic character of the ceramic assemblage suggests that it was most likely accumulated between ca. A.D. 1520-1560. At 2 sigma (95.4 percent probability), the six calibrated radiocarbon dates from the site's archaeological deposits have median probabilities that range from A.D. 1462-1559, and those in stratigraphic order by depth range from A.D. 1506-1559. By calibrated age range, those with the highest probabilities that are in stratigraphic order by depth are A.D. 1448-1524, A.D. 1448-1526, A.D. 15131600, A.D. 1539-1635, and A.D. 1544-1634.

The ceramic sherds are from vessels tempered with grog, although burned bone or hematite were also regularly added to the paste of vessels. These sherds are from plain ware, utility ware, and fine ware vessels. The utility wares are from jars that have been decorated on the rim and/or the body with brushed, brushed-incised, brushed-punctated, incised, and punctated elements (Figure 2), while the few fine sherds are from carinated bowls or bottles with engraved or red-slipped decorative elements. Defined utility ware ceramic types present in the assemblage include Bullard Brushed, Killough Pinched, La Rue Neck Banded, Lindsey Grooved, Maydelle Incised, and Saunders Punctated, all known to occur in Frankston phase contexts in the region. The fine ware sherds from the Shackleford Creek site are from Poynor Engraved, var. Cook and var. Hood vessels (Figure 3).

The plain and decorated pipe sherds in the Shackleford Creek artifact assemblage are from elbow pipes (Figure 4), known to have been produced in the upper Neches and Angelina River basis after ca. A.D. 1400. The recognized varieties from the site - var. C and var. $\mathrm{G}$ - are present in large elbow pipe assemblages
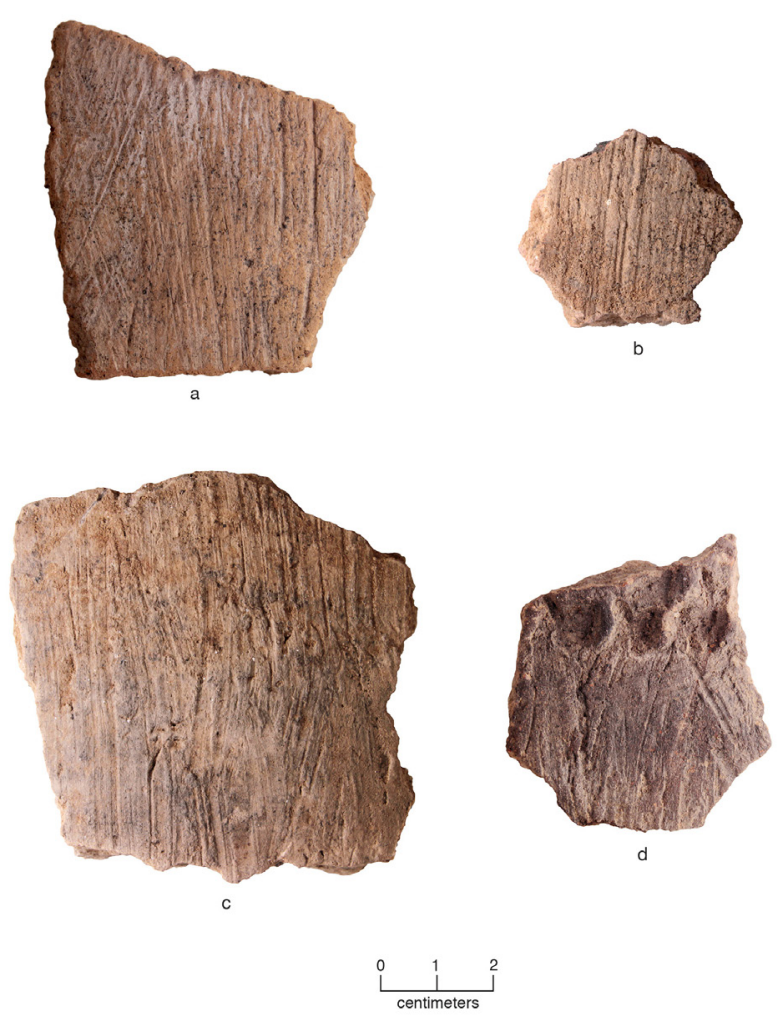

Figure 2. Selected decorated brushed and brushed-punctated sherds from the Shackleford Creek site: a, parallel-overlapping brushed marks (Lot 1.1); b, parallel brushed marks (Lot 23.7); c, parallel brushed marks (Lot 24.1); d, brushed-punctated (Lot 29.5).

in the region that date from ca. A.D. 1480-1680 (see Perttula 2011).

The many pieces of small burned clay in the archaeological deposits at the site may be the remnants of the lining of hearths or other features likely present at the site where a clay lining was exposed to heat, and then fragmented and spread into the archaeological deposits. The daub, with small stick impressions, may have come from the burning of some section of a grassthatched structure on the site.

Chipped stone tools are uncommon in the archaeological deposits at the Shackleford Creek site. They include two Perdiz arrow points, a scraper, and a bilateral flake tool. These tools are primarily made from non-local cherts, most likely obtained from Central Texas sources. The lithic debris $(n=59)$ from the test excavations at the Shackleford Creek site is uniformly small in size (less than $3 \mathrm{~mm}$ in length), and most likely is the product of the maintenance and resharpening of chipped stone tools by Caddo knappers that had not 


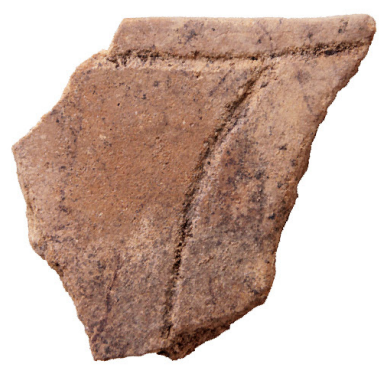

a

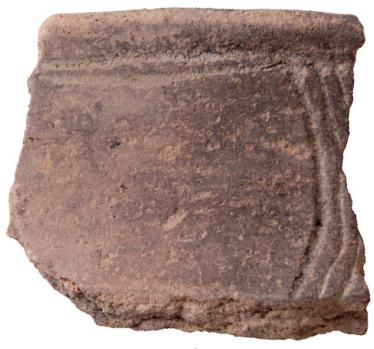

b

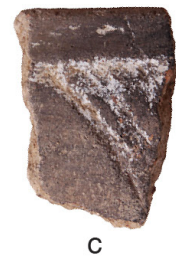

C
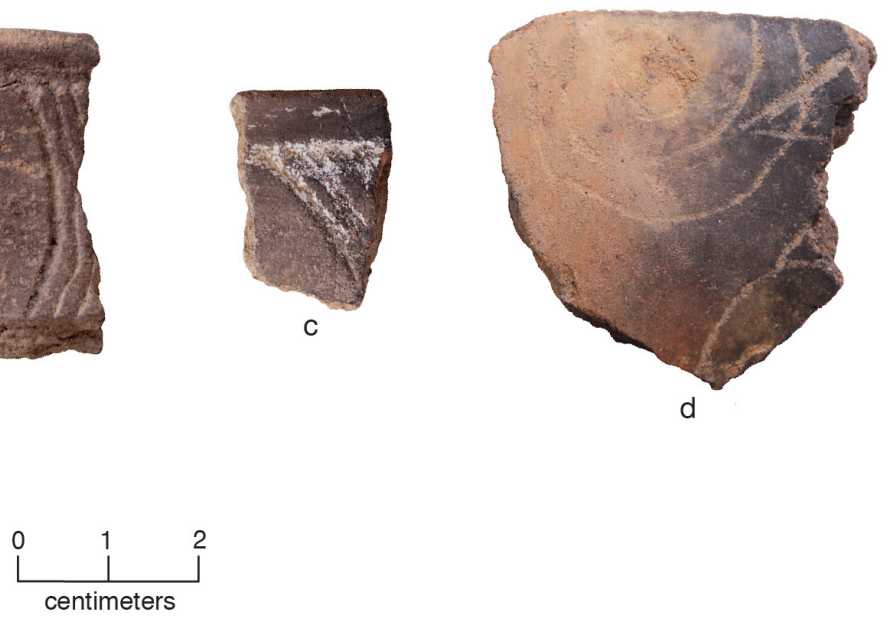

Figure 3. Selected Poynor Engraved sherds from the Shackleford Creek site: a, Poynor Engraved, var. Cook (Lot 56.6); b, Poynor Engraved, var. Cook (Lot 72.1); c, Poynor Engraved, var. Hood (Lot 58.3); d, Poynor Engraved, var. unspecified bottle sherd (Lot 33.5).

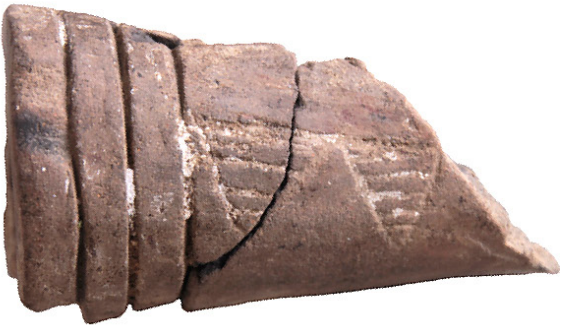

a
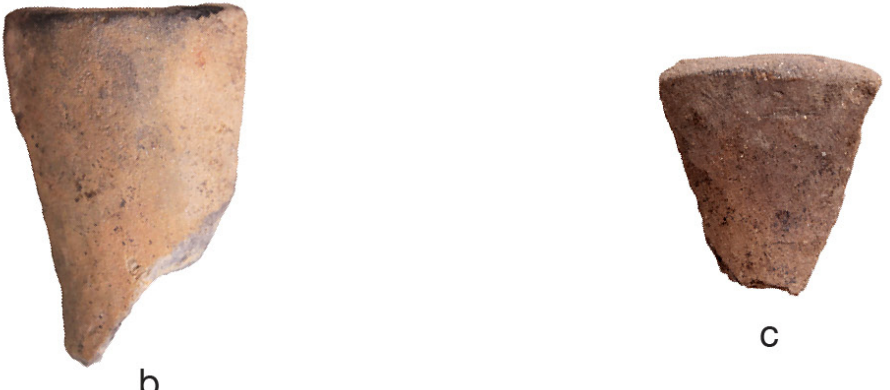

C

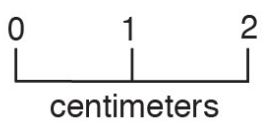

Figure 4. Elbow pipe sherds from the Shackleford Creek site:a, engraved elbow pipe stem rim (Lot 73.1); b, plain elbow pipe stem rim (Lot 74.3); c, plain elbow pipe bowl rim (Lot 61.2).

been made on site, but were brought to the site from elsewhere. Raw materials of non-local origin comprise 77 percent of the lithic debris assemblage knapped at the site.

In addition to material culture remains from the site's preserved ancestral Caddo archaeological deposits, the Shackleford Creek site also contains charred plant remains as well as animal bones in $1 / 4$-inch and flotation samples. The charred plant remains (Bush 2019) consist of the near ubiquitous occurrence of domesticated corn (Zea mays) cupules and kernels, a major source of food production after ca. A.D. 1300-1400 in East Texas by Caddo peoples (see Perttula et al. 2014; Wilson 2012; Wilson and Perttula 2013), hickory and acorn nutshell, and starchy and oily seeds of chenopods, maygrass, and amaranth; these are from native crops that are part of the Eastern Agricultural Complex (Gremillion 2018:12-37). Other wild plant foods preserved in the archaeological deposits are sumac, blackberry, and elderberry seeds, wild legume or bean seeds, and purslane seeds. Oak and pine wood charcoal is also present. Overall, plant remains recovered at the Shackelford Creek site are 
typical of ancestral Caddo farmsteads in the Caddo area, with corn and nutshell well represented but other crops and wild plants relatively scarce. The data for corn cupule dimensions is consistent with the corn grown at other Caddo sites in the area.

The faunal remains from the site are dominated by white-tailed deer and large mammal-sized bone (Corl 2019). The remainder includes turtles, birds, and rabbit- and dog-sized faunal remains, the latter mammals that supplemented their diet. White-tailed deer were a key food resource for those living at the Shackleford Creek site, which is consistent with other ancestral Caddo Frankston phase sites in the upper Neches River basin. Deer were important resources for the Caddo people not just for their meat, but also for their pelts and bones.

We have recommended that the Shackleford Creek site is eligible for inclusion in the NRHP under criteria d because it has "yielded, or may be likely to yield, information important in history or prehistory." Based on the results of the test excavations, the Shackleford Creek site can contribute new and important information on Late Caddo (ca. A.D. 1400-1680) Frankston phase residential settlements or households in the region. Specifically, it contains preserved archaeological deposits and archaeological data from an important property type in the upper Angelina River basin that can address several research issues in "The Development of Agriculture in Northeast Texas before A.D. 1600" (Perttula 1993) historic context developed by the Texas Historical Commission as part of their Preservation Plan for the region.

\section{References Cited}

Bush, L. L.

2019 Macrobotanical Remains from the Shackleford Creek Site (41SM494), Smith County, Texas. In Test Excavations at the Shackleford Creek Site (41SM494) in the Upper Angelina River Basin, Smith County, Texas, by T. K. Perttula, B. Nelson, L. L Bush, and K. Corl. Report of Investigations No. 7. Tejas Archaeology, Pittsburg, Texas, in press.
Corl, K.

2019 Zooarchaeological Analysis of Faunal Remains from the Shackleford Creek Site (41SM494). In Test Excavations at the Shackleford Creek Site (41SM494) in the Upper Angelina River Basin, Smith County, Texas, by T. K. Perttula, B. Nelson, L. L Bush, and K. Corl. Report of Investigations No. 7. Tejas Archaeology, Pittsburg, Texas, in press.

Gremillion, K. J.

2018 Food Production in Native North America: An Archaeological Perspective. The SAA Press, Washington, D.C.

Nelson, B. and T. K. Perttula

2018 Archaeological Survey of the Shackleford Creek Residential Development Project, Smith County, Texas. Letter Report No. 74. Tejas Archaeology, Pittsburg.

Perttula, T. K.

1993 The Development of Agriculture in Northeast Texas before A.D. 1600. In Archeology in the Eastern Planning Region, Texas: A Planning Document, edited by N. A. Kenmotsu and T. K. Perttula, pp. 121-146. Cultural Resource Management Report 3. Department of Antiquities Protection, Texas Historical Commission, Austin.

2011 The Ceramic Artifacts from the Lang Pasture Site (41AN38) and the Place of the Site within an Upper Neches River Basin Caddo Ceramic Tradition. In Archeological Investigations at the Lang Pasture Site (41AN38) in the Upper Neches River Basin of East Texas, assembled and edited by T. K. Perttula, D. B. Kelley, and R. A. Ricklis, pp. 145-320. Archeological Studies Program Report No. 129, Texas Department of Transportation, Environmental Affairs Division, Austin. 
Perttula, T. K., B. Nelson, L. L. Bush, and K. Corl

2019 Test Excavations at the Shackleford Creek Site (41SM494) in the Upper Angelina River Basin, Smith County, Texas. Report of Investigations No. 7. Tejas Archaeology, Pittsburg, Texas.

Perttula, T. K., R. Z. Selden, Jr., and D. Wilson

2014 Corn is Life: Temporal Trends in the Use of Corn (Zea mays) by Caddo Peoples from Radiocarbondated Samples and Stable Isotope Analyses.

Bulletin of the Texas Archeological Society 85:159-181.
Wilson, D.

2012 Bioarchaeological Evidence of Subsistence Strategies among the East Texas Caddo. In The Archaeology of the Caddo, edited by T. K. Perttula and C. P. Walker, pp. 86-116. University of Nebraska Press, Lincoln.

Wilson, D. and T. K. Perttula

2013 Reconstructing the Paleodiet of the Caddo through Stable Isotopes. American Antiquity 78(4):702723. 